\title{
Autotaxin upregulated by STAT3 activation contributes to invasion in pancreatic neuroendocrine neoplasms
}

\author{
Linfei Yang ${ }^{1}$, Xiao $\mathbf{Y u}^{2}$ and Yongchao Yang ${ }^{3,4}$ \\ ${ }^{1}$ Center for Medical Experiments, The Third Xiangya Hospital, Central South University, Changsha, China \\ ${ }^{2}$ Department of General Surgery, The Third Xiangya Hospital, Central South University, Changsha, China \\ ${ }^{3}$ Department of Burns and Plastic Surgery, The Third Xiangya Hospital, Central South University, Changsha, China \\ ${ }^{4}$ European Pancreas Center, Department of General, Visceral and Transplantation Surgery, Heidelberg University Hospital, Heidelberg, Germany \\ Correspondence should be addressed to Y Yang: yyc198310@sina.com
}

\begin{abstract}
Although the upregulation of autotaxin (ATX) is associated with many solid tumours, its role in pancreatic neuroendocrine neoplasms ( $\mathrm{PNEN}$ ) has not been well elucidated. The expression of ATX in pNEN tissues and pNEN cell line BON1 was analysed by Western blot, PCR and immunocytochemistry upon exposure to interleukin-6 (IL-6). Additionally, pNEN cell line BON1 was transfected with siRNAs against ATX or signal transducer and activator of transcription 3 (STAT3) and assessed by in vitro invasion assays. The following results were obtained. The expression of ATX in PNEN tissues was significantly increased compared with that in normal pancreatic tissues. High ATX expression was strongly correlated with tumour grade, lymph node metastasis and tumour-nodemetastasis stage. Furthermore, ATX downregulation notably inhibited the metastatic capacity of pNEN cells, whereas STAT3 knockdown was found to downregulate the expression of ATX. ATX expression was upregulated in BON1 cells upon stimulation with IL-6, and this was accompanied by activation/phosphorylation of STAT3. Western blot analysis of human pNEN tissue extracts confirmed increased ATX expression and STAT3 phosphorylation with elevated expression levels of IL-6. In conclusion, ATX is upregulated in pNEN and is correlated with the metastatic capacity of pNEN cells, potentially via interaction with STAT3 activation.
\end{abstract}

\author{
Key Words \\ - ATX \\ - pancreatic neuroendocrine \\ neoplasms \\ - pNEN \\ - signal transducer and \\ activator of transcription 3 \\ - invasion
}

Endocrine Connections (2018) 7, 1299-1307

\section{Introduction}

The incidence of pancreatic neuroendocrine neoplasm $(\mathrm{pNEN})$, the most aggressive neuroendocrine malignancy among gastroenteropancreatic neuroendocrine neoplasms (GEP-NENs), has increased significantly over the past few decades, with the incidence rate increasing approximately 4.6-fold from 1973 (0.18 per 100,000) to 2012 (0.82 per $100,000)$ in the United States $(1,2,3)$. PNEN is a clinically rare and heterogeneous disease of the pancreas with variable clinical presentation that depends on histological features and disease staging, resulting in widely variable prognoses for different pNENs (4). Therefore, there is a critical need to better define the molecular features associated with prognosis in these tumours.

Autotaxin (ATX), or nucleotide pyrophosphatasephosphodiesterase 2 (ENPP2), is a secreted glycoprotein with lysophospholipase $\mathrm{D}$ activity that primarily catalyses the hydrolysis of lysophosphatidylcholine, resulting in lysophosphatidic acid (LPA) production $(5,6)$. ATX was initially identified as an autocrine motility factor in human melanoma cells, and it is endogenously expressed in multiple tissues such as the ovary, intestine, kidney, prostate, testis, colon and lung $(7,8,9)$. Proper regulation
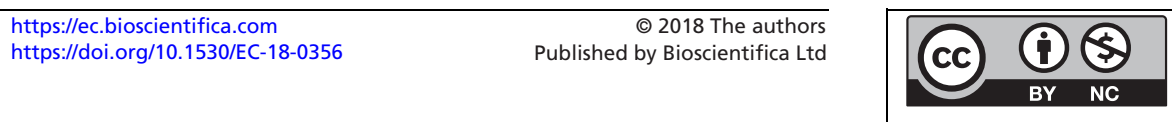
of the expression and activity of ATX was found to play an essential role in embryogenesis by regulating vasculature maturation and angiogenesis, and this activity was responsible for the correct concentration of LPA in plasma $(10,11,12)$.

Signal transducer and activator of transcription 3 (STAT3) is a crucial regulator of gene expression in response to signalling of the glycoprotein 130 (gp130) family of cytokines that includes IL-6 (13). The STAT3 signalling pathway plays a key role in regulating growth, survival, differentiation and pathogen resistance (14). Constitutive activation of the STAT3 signalling pathway has been observed in several human cancers, including breast cancer, multiple myeloma, head and neck cancer, ovarian cancer and prostate cancer $(15,16,17,18)$. The activation/phosphorylation of STAT3 is dependent on certain cytokines (19). One of these cytokines, IL-6, is suspected of mediating malignant behaviours in various cancers, including breast cancer, renal cell carcinoma, gastric cancer and colorectal cancer, by enhancing the expression of angiogenesis-related genes such as VEGF $(20,21,22,23)$. ATX has been reported to be a target of STAT3 transcriptional regulation in breast cancer (24).

Recently, ATX was reported to play an important role in the development and progression of some tumour types (8). Elevated levels of ATX have been demonstrated to be positively associated with the aggressive behaviour of tumours including renal cell carcinoma (25), hepatocellular carcinoma (26), melanoma (11), ovarian cancer (27) and breast cancer (28). However, to the best of our knowledge, the potential role of ATX in promoting the progression of pNEN has not been reported. Therefore, in the present study, we aimed to explore the underlying mechanisms of ATX and its possible usefulness in improving treatment and determining the prognosis of pancreatic neuroendocrine neoplasms.

\section{Materials and methods}

\section{Clinical samples}

A total of 34 snap-frozen tumour tissues $(n=17)$, paired normal adjacent pancreatic tissues $(n=17)$ and paraffinembedded tissues $(n=34)$ from patients with pNENs were obtained from the Department of General Surgery, The Third Xiangya Hospital, Central South University (Changsha, China). The study was approved by The Third Xiangya Hospital Clinical Research Ethics Committee. Consent was obtained from each patient after full

$$
\text { https://ec.bioscientifica.com }
$$

explanation of the purpose and nature of all procedures used. Samples were stored at $-80^{\circ} \mathrm{C}$ (frozen tissue) or room temperature (paraffin samples) for expression analysis by quantitative reverse transcriptase PCR, Western blot and/or immunohistochemistry. None of the patients had received radiotherapy or chemotherapy prior to surgery. The diagnosis of all pNEN patients was based on the results of pathological sections. Tumour grade was determined according to the World Health Organization (WHO) grading system (29).

\section{Cell culture}

The human metastatic, adherent pNEN cell line, BON1, was obtained from the American Type Culture Collection and grown as a monolayer in $75 \mathrm{~cm}^{2}$ flasks (Corning, NY, USA) in a 1:1 mixture of RPMI 1640 and Ham's F-12 media supplemented with $10 \%$ foetal bovine serum, penicillin and streptomycin $(100 \mathrm{IU} / \mathrm{mL})$ at $37^{\circ} \mathrm{C}$ with $5 \%$ $\mathrm{CO}_{2}$ (30). To investigate the role of interleukin-6 (IL-6) in the activation of STAT3, BON1 cells were treated with recombinant human IL-6 $\left(25 \mathrm{ng} \mathrm{mL}^{-1}\right)$ (Cell Signaling Technology) for different periods $(24 \mathrm{~h}, 48 \mathrm{~h}, 72 \mathrm{~h})$. The period (72h) at which IL-6 exerted its maximum effect on BON1 cells was chosen for study.

\section{Protein extraction and Western blot analysis}

Proteins from tissue $(1 \times 2 \mathrm{~mm})$ or $\mathrm{BON} 1$ cells were extracted using RIPA buffer containing complete protease inhibitors (Sigma-Aldrich) according to the manufacturer's instructions, and the protein concentration was determined using a BCA Protein Determination Kit (Thermo Scientific) following the manufacturer's instructions. Western blots were processed as previously described (31) using the following antibodies: anti-IL-6, anti-total-STAT3, and anti-ATX (all from Abcam); and anti-phospho-STAT3 (Tyr705) (Cell Signaling Technology). A goat anti-rabbit secondary antibody was used (R\&D Systems). Protein expression was quantified using ImageJ (NIH).

\section{Immunohistochemistry}

The expression of ATX was assessed on paraffin-embedded primary tumour samples by immunohistochemistry as previously described (32). Briefly, tissue sections were deparaffinised and rehydrated in a graded ethanol series. Heat-based antigen retrieval was carried out in citrate buffer. Tissue sections were then blocked with Universal Blocking Reagent (BioGenex, Fremont, CA, USA) and 
incubated with anti-ATX antibody (Cell Signalling), before being washed and developed using goat anti-rabbit secondary antibody (Santa Cruz Biotechnology) and a DAB kit (Cell Signaling Technology). After the tissue sections were counterstained with haematoxylin and washed with water, they were incubated in graded alcohol solutions and mounted. Optical image capture and analysis were performed using a microscope (IX71; Olympus Corp.). The evaluation method of staining widely used by pathologists in pathological analysis was performed as previously described (33). Briefly, staining intensity was scored as 0 (no staining), 1 (light yellow), 2 (brown) or 3 (tan), for absent, weak, moderate or strong, respectively, and the staining percentage was given a score of 0 (absent) for $<5 \%$ positive staining, 1 (focal) for $5-<50 \%$ positive staining or 2 (diffuse) for $\geq 50 \%$ positive staining. The sum of the intensity and distribution scores was then used to determine ATX immunoreactivity. A score of 1 or 0 was considered to be indicative of low expression, whereas higher scores were considered to indicate high expression. Two pathologists assessed the specimens independently according to double-blind method. Negative slides were processed in the absence of primary antibody.

\section{RNA extraction and quantitative reverse transcriptase PCR (qRT-PCR)}

Total RNA was extracted from fresh specimens using TRIzol reagent (Thermo Fisher Scientific) according to the manufacturer's instructions. cDNA was prepared using a Superscript III cDNA Synthesis kit (Takara Bio, Inc.) following the manufacturer's protocol. qRT-PCR was performed using the FastStart Essential DNA Green Master mix (Roche Diagnostics) with the following primer pairs: ATX 5'-CGTGAAGGCAAAGAGAACACG3'/5'-AAAAGTGGCATCAAATACAGG-3' and GAPDH 5'-ATGTTCGTCATGGGTGTGAA-3' / 5' -GTCTTCTGG GTGGCAGTGAT-3'.

Quantitative PCR was performed in a $20 \mu \mathrm{L}$ reaction solution containing $6 \mu \mathrm{L}$ of nuclease-free water, $2 \mu \mathrm{L}$ of cDNA template, $10 \mu \mathrm{L}$ of Master Mix and $1 \mu \mathrm{L}$ each of the forward and reverse primers. The amplification conditions were as follows: initial denaturation at $95^{\circ} \mathrm{C}$ for $15 \mathrm{~min}$, followed by 45 cycles of denaturation at $95^{\circ} \mathrm{C}$ for $10 \mathrm{~s}$, annealing at $60^{\circ} \mathrm{C}$ for $30 \mathrm{~s}$ and elongation at $72^{\circ} \mathrm{C}$ for $20 \mathrm{~s}$. The experiment was performed in triplicate. Qualitative PCR was also performed to confirm the presence of single, appropriately sized bands for each primer set. PCR data were analysed using the $\Delta \Delta \mathrm{CT}$ method as previously described (34).

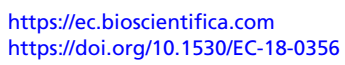

\section{ATX and STAT3 sIRNA transfection}

To specifically inhibit ATX and STAT3, siRNAs targeting these two proteins were used. The BON1 cells were cultured in 6-well plates $\left(3.0 \times 10^{5}\right.$ cells/well $)$ for $72 \mathrm{~h}$ prior to transfection. Subsequently, ATX siRNA $(20 \mu \mathrm{mol} / \mathrm{L}$; Thermo Fisher Scientific) and STAT3 siRNA (20 $\mu \mathrm{mol} / \mathrm{L}$; Thermo Fisher Scientific) were individually transfected into the BON1 cells. Negative control siRNA ( $20 \mu \mathrm{mol} / \mathrm{L}$; Thermo Fisher Scientific) was used as a negative control in parallel. Transfections were performed with HiPerFect (Invitrogen) according to the manufacturer's protocol. Knockdown effectiveness was assessed by Western blot for total ATX and STAT3 levels.

\section{Cell migration and invasion assay}

A 24-well plate containing a $12-\mu \mathrm{m}$ pore size polycarbonate membrane insert (Corning) coated with a uniform layer of dried basement membrane matrix solution (Corning) on the upper surface of the insert membrane was used for BON1 cell migration and invasion assays as previously described (35). Briefly, the lower compartment was filled with RPMI 1640/Ham's-F12 medium containing 30\% FBS. After $48 \mathrm{~h}$ of transfection, single-cell suspensions $\left(3 \times 10^{5}\right.$ cells/well in a volume of $\left.300 \mu \mathrm{L}\right)$ of BON1 cells were added to the upper chamber of each insert. After $48 \mathrm{~h}$ of incubation at $37^{\circ} \mathrm{C}$ in a $5 \% \mathrm{CO}_{2}$ atmosphere, the inserts were removed, and cells on the upper surface of the insert membrane were removed with a cotton swab. The invaded cells were fixed and stained with $0.05 \%$ crystal violet. Membranes were excised. Cells that were able to invade or migrate (located on the bottom of the membrane) were counted with a microscope (IX71; Olympus Corp.) in nine individual fields per membrane.

\section{Statistical analysis}

Statistical analyses were performed using Prism 5 (GraphPad Software). Differences between two groups were estimated with Student's $t$ test or Fisher's exact test as appropriate. Data were presented as the mean \pm standard deviation. A $P$ value $<0.05$ was considered statistically significant.

\section{Results}

\section{ATX expression is upregulated in pNENs}

The expression of ATX in pNEN and matched adjacent normal pancreatic tissue samples was detected by qRT-PCR and immunohistochemistry. As shown in

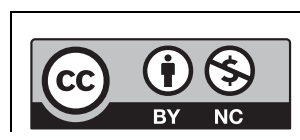

This work is licensed under a Creative Commons Attribution-NonCommercial 4.0 International License. 
Fig. 1, the expression of ATX was significantly higher in pNEN tissues than that in the matched adjacent normal pancreatic tissues.

\section{ATX expression levels are significantly correlated with tumour grade, lymph node metastasis and TNM stage}

Our previous studies showed that ATX expression in pNEN tissues is significantly increased compared with that in matched adjacent normal pancreatic tissues. To investigate the associations between ATX expression and pNEN clinicopathologic characteristics, we performed immunohistochemistry to detect ATX expression in 34 paraffin-embedded pNEN tissues. The results revealed that $22(64.7 \%)$ of 34 patients with pNEN exhibited high ATX expression and that ATX expression was significantly lower in normal pancreatic tissues than in pNEN tissues. The relationships between ATX expression and clinicopathological pNEN features are shown in Table 1. Our results indicate that high ATX expression was positively correlated with tumour grade $(P=.029)$, lymph node metastasis $(P=.013)$ and TNM stage $(P=.012)$.

\section{ATX and STAT3 affect the invasion capacity of BON1 cells}

To investigate the role of ATX in the development and progression of pNEN, BON1 cells were transfected with ATX or STAT3 siRNA, and the effects on cell invasion were investigated using a cell invasion assay (Fig. 2). The expression of ATX and STAT3 in BON1 cells transfected

\section{A}

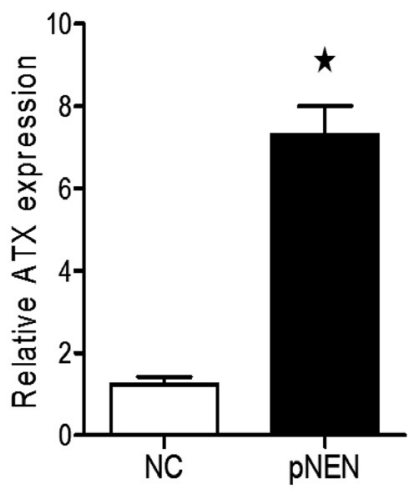

B

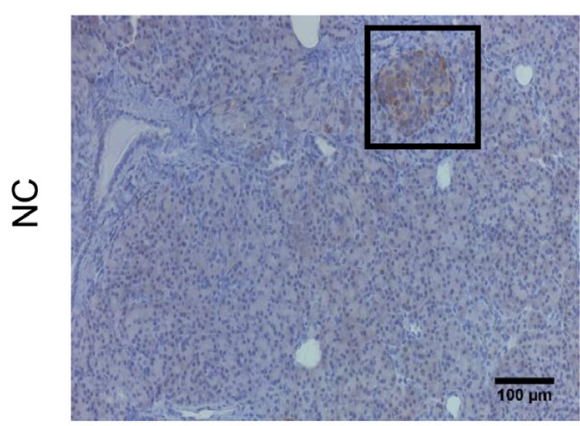

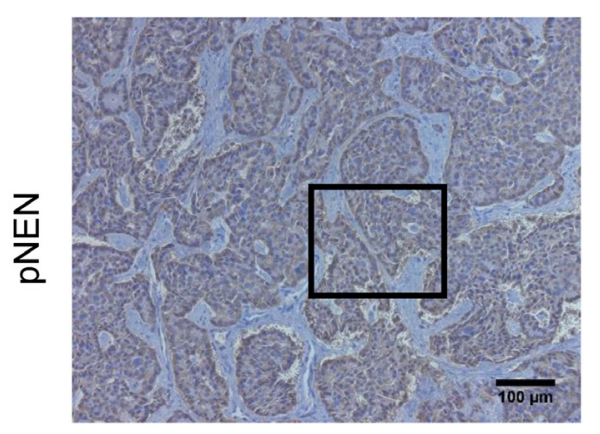

$10 \times$
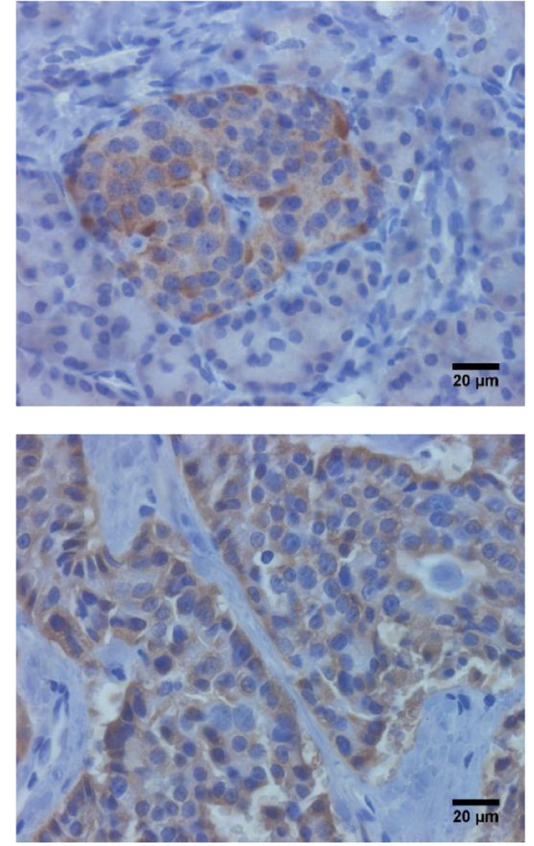

$40 \times$
Figure 1

Expression of ATX in pNEN tissues. (A) Human pNEN tissues and matched adjacent NC tissues were tested by RT-qPCR for the expression of ATX. (B) Immunohistochemical analysis of ATX expression in tumour and normal control tissues. Student's t test was used for statistics analysis. $\star P<0.001$ vs NC. ATX, autotaxin; NC, normal control; pNEN, pancreatic neuroendocrine neoplasms. https://ec.bioscientifica.com

https://doi.org/10.1530/EC-18-0356 (c) 2018 The authors Published by Bioscientifica Ltd

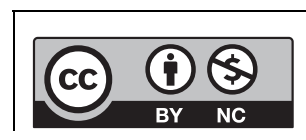
This work is licensed under a Creative Commons
Attribution-NonCommercial 4.0 International License. 
Table 1 Correlations between ATX expression and the clinicopathologic variables of 34 pNEN patients.

\begin{tabular}{|c|c|c|c|c|}
\hline \multirow[b]{2}{*}{ Variables } & \multirow[b]{2}{*}{ No. } & \multicolumn{2}{|c|}{ NRP-1 expression } & \multirow[b]{2}{*}{$\boldsymbol{P}$} \\
\hline & & Low $(n=12)$ & High $(n=22)$ & \\
\hline \multicolumn{5}{|l|}{ Sex } \\
\hline Male & 19 & 6 & 13 & \multirow[t]{2}{*}{.724} \\
\hline Female & 15 & 6 & 9 & \\
\hline \multicolumn{5}{|l|}{ Age } \\
\hline$\leq 60$ & 20 & 8 & 12 & \multirow[t]{2}{*}{.717} \\
\hline$>60$ & 14 & 4 & 10 & \\
\hline \multicolumn{5}{|c|}{ Tumour localisation } \\
\hline Head & 18 & 7 & 11 & \multirow[t]{2}{*}{.728} \\
\hline Body and tail & 16 & 5 & 11 & \\
\hline \multicolumn{5}{|l|}{ Tumour size $(\mathrm{cm})$} \\
\hline$\leq 2 \mathrm{~cm}$ & 13 & 6 & 7 & \multirow[t]{2}{*}{.462} \\
\hline$>2 \mathrm{~cm}$ & 21 & 6 & 15 & \\
\hline \multicolumn{5}{|c|}{ Lymph node metastasis } \\
\hline No & 18 & 10 & 8 & \multirow[t]{2}{*}{$.013^{\circ}$} \\
\hline N1 & 16 & 2 & 14 & \\
\hline \multicolumn{5}{|l|}{ TNM stage } \\
\hline I-II & 15 & 9 & 6 & \multirow[t]{2}{*}{$.012^{\circ}$} \\
\hline III-IV & 19 & 3 & 16 & \\
\hline \multicolumn{5}{|c|}{ Grading (WHO 2010) } \\
\hline G1-G2 & 16 & 9 & 7 & \multirow[t]{2}{*}{$.029^{\circ}$} \\
\hline G3 & 18 & 3 & 15 & \\
\hline \multicolumn{5}{|l|}{ Type } \\
\hline Insulinomas & 7 & 3 & 4 & \multirow[t]{2}{*}{.676} \\
\hline Nonfunctional & 27 & 9 & 18 & \\
\hline
\end{tabular}

with ATX and STAT3 siRNAs was significantly inhibited (Fig. 2A and B). The number of invaded BON1 cells on the bottom of the membrane was significantly reduced after transfection with ATX or STAT3 siRNA (Fig. 2C, D, E and F) compared with negative control transfection. These data indicated that ATX and STAT3 affected the invasion capacity of the BON1 cells.

\section{ATX may be a direct target of STAT3}

ATX was predicted to be a downstream target of STAT3 from genecard database (http://www.genecards.org/) by using bioinformatics tools including BLAST and PathCards (36). To test this hypothesis in pNEN, Western blot was used to detect the expression of ATX following the downregulation of STAT3 expression. As shown in Fig. 3, in BON1 cells, the siRNA-mediated downregulation of STAT3 caused a significant reduction in ATX protein expression. These findings indicated that ATX may be a direct target of STAT3.

\section{IL-6 expression in human pNEN is associated with STAT3 pathway activation}

It has been demonstrated that IL-6 impacts the metastatic behaviour of various tumours (37). We examined IL-6 expression and invasive signalling pathways in human pNEN tissues. By Western blot analysis, IL-6 expression was significantly higher in pNEN tissues than that in paired adjacent normal pancreatic tissues. Additionally, increased IL-6 levels were associated with increased phosphorylation of STAT3 (Fig. 4).

\section{Impact of IL-6 on signalling pathways in BON1 cells}

To examine the impact of IL-6 on signalling pathways in BON1 cells, we first determined STAT3 expression in IL-6-treated BON1 and control cells. IL-6 treatment led to robust STAT3 activation as reflected by increased STAT3 phosphorylation in IL-6-treated BON1 cells compared to control cells, which did not show any STAT3 phosphorylation (Fig. 5A, B and C). ATX expression was investigated and shown to be strongly upregulated in IL-6-treated BON1 cells (Fig. 5A and B).

\section{Discussion}

In the present study, we showed that ATX expression level was significantly upregulated in pNEN tissues compared with adjacent normal pancreatic tissues and that high ATX expression was positively correlated with tumour grade, lymph node metastasis and TNM stage. Additionally, the function of ATX in the pNEN cell line BON1 was investigated, and we found that ATX downregulation suppressed the invasive capacity of BON1 cells. In this study, we also showed that pNEN cell line BON1 upregulated ATX expression when stimulated by IL-6. Furthermore, STAT3 signalling was implicated as a critical effector pathway in response to IL-6 treatment. These in vitro observations were consistent with observations in human neuroendocrine disease, in which increased ATX expression and STAT3 phosphorylation were identified in pNEN tissues with elevated IL-6 expression levels.

The expression of ATX has been reported to be upregulated in many different types of cancer and to be associated with the oncogenesis and development of these cancers (8). Kishi et al. showed that the overexpression of ATX in glioblastoma contributed to the invasiveness of cancer cells by converting lysophosphatidylcholine to LPA (38). Yang et al. reported that ATX expression was closely linked to the invasiveness of breast cancer cells (39). The overexpression of ATX has also been demonstrated to be positively correlated with the migratory behaviour of thyroid carcinomas (40). Similar observations were identified in our studies, and in these pNENs, significant https://ec.bioscientifica.com

https://doi.org/10.1530/EC-18-0356
(C) 2018 The authors Published by Bioscientifica Ltd
This work is licensed under a Creative Commons Attribution-NonCommercial 4.0 International License. 
A

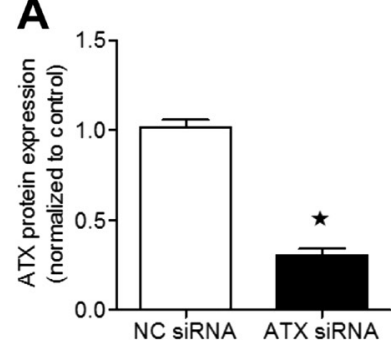

C Invaded cells
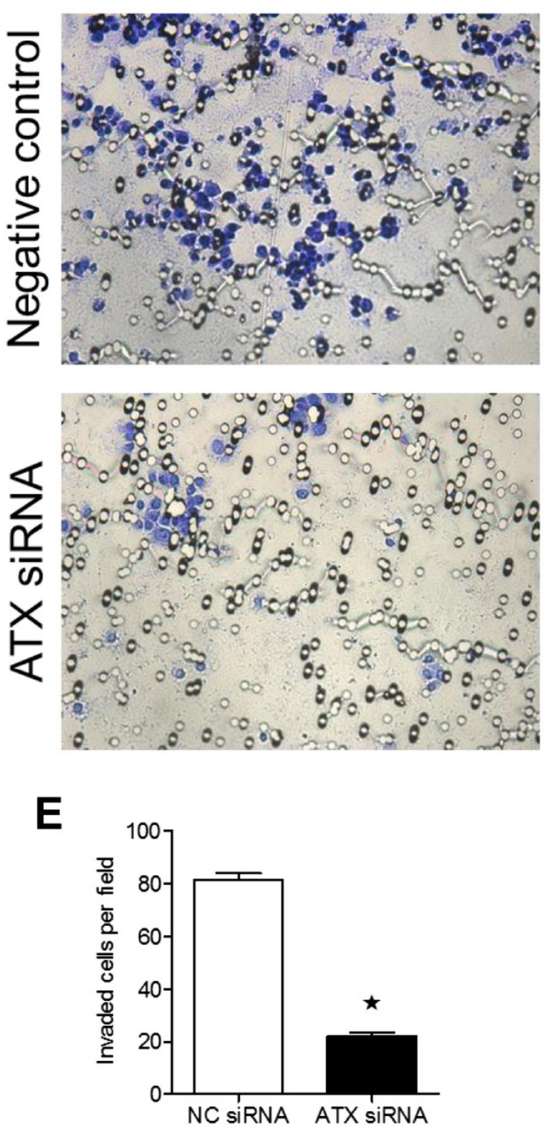
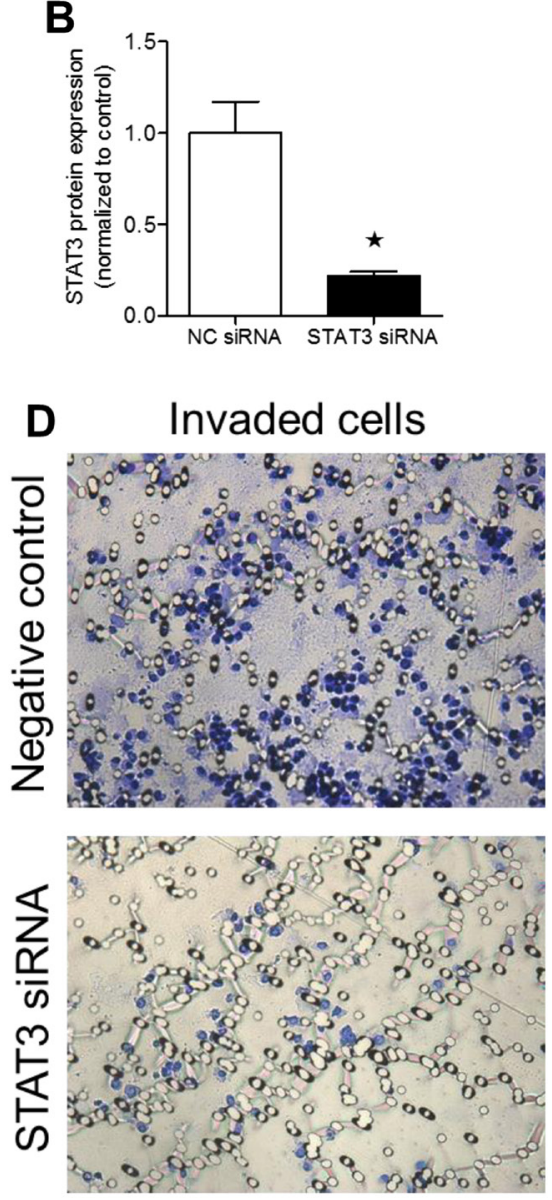

$\mathbf{F}$

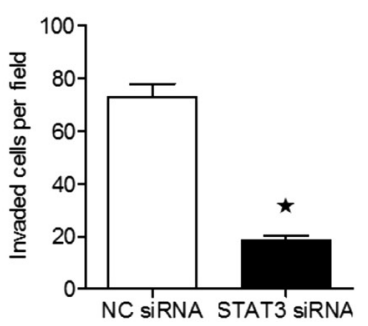

Figure 2

The impact of ATX and STAT3 on the invasive capacity of BON1 cells. (A) Relative ATX expression levels in negative control and ATX siRNA-treated BON1 cells. (B) Relative STAT3 expression in negative control and STAT3 siRNA-treated BON1 cells. (C and D) Cell invasion assays (magnification, 400x). (C and E) Knockdown of ATX strongly decreased the invasive capability of BON1 cells compared with the negative control. ( $D$ and $F$ ) BON1 cells transfected with STAT3 siRNA exhibited decreased invasion compared with those transfected with the negative control. Experiments were performed thrice and representative images of invaded cells are shown. Data are presented as mean \pm S.D. of three independent experiments. Student's $t$ test was used for statistics analysis. $\star P<0.01$ vs NC. ATX, autotaxin; NC, normal control; siRNA, small interfering RNA; STAT3, signal transducer and activator of transcription 3.
ATX expression was found only in cancerous tissue not in paired adjacent normal pancreas tissue. In this study, we also showed that high ATX expression was positively correlated with tumour stage, lymph node metastasis and tumour grade and that the downregulation of ATX suppressed the invasive capacity of BON1 cells, indicating that ATX might play a crucial role in the metastasis of pNEN.

It has been suggested that IL-6 expression is increased in the tumour microenvironment (41). IL-6 was found to contribute to the development and progression of various malignancies $(20,21,37)$. Furthermore, the IL-6 signalling pathway, especially the IL-6/STAT3 signalling pathway, ultimately leads to transcriptional changes

$\begin{array}{lr}\text { https://ec.bioscientifica.com } & \text { () } 2018 \text { The authors } \\ \text { https://doi.org/10.1530/EC-18-0356 } & \text { Published by Bioscientifica Ltd }\end{array}$

that impact survival, proliferation, differentiation and migration (42). We examined the effects of IL-6 treatment on ATX expression and signalling pathways in BON1 cells and demonstrated that ATX expression was increased upon IL-6 exposure. The response of BON1 cells to IL-6 is most likely mediated by STAT3 activation, which has been reported to be associated with many tumours that have a poor prognosis, including bladder cancer (43). Our data showed that the effect of IL- 6 on ATX upregulation in BON1 cells is likely mediated via STAT3 activation. It is unknown whether IL-6 is produced by pancreatic neuroendocrine tumour cells, but it has been reported that IL-6 was derived from intratumoral immune cells including tumour-associated macrophages (44).

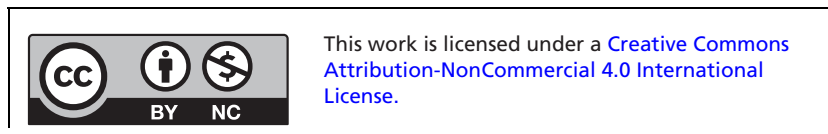


A
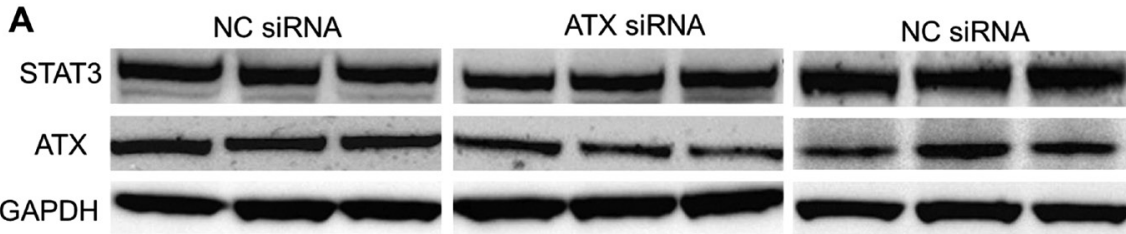

STAT3 SIRNA

B

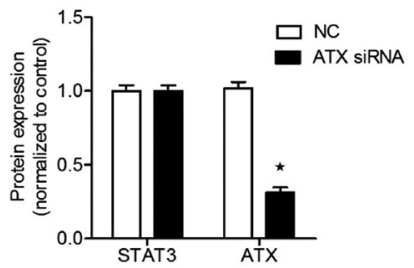

C

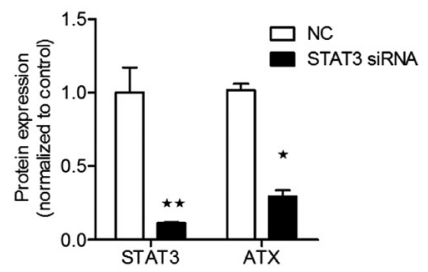

Figure 3

(A and B) Transfection with ATX siRNA downregulated the protein expression of ATX in BON1 cells. (A and C) Transfection with STAT3 siRNA decreased the protein levels of STAT3 and ATX in BON1 cells. Experiments were performed thrice and blots are representative of one experiment. Data are presented as mean \pm S.D. of three independent experiments. Student's $t$ test was used for statistics analysis. $P<0.05$ vs NC. ${ }^{\star} P<0.01$ vs NC. ATX autotaxin; NC, normal control; siRNA, small interfering RNA; STAT3, signal transducer and activator of transcription 3.

To investigate the possible function of ATX and to reveal its underlying molecular mechanisms, the identification of regulatory targets is required. In this study of BON1 cells, the downregulation of STAT3 expression caused a reduction in the ATX protein level. This finding indicated that ATX may be a target of STAT3. STAT3 has previously been reported to be overexpressed and to be associated with malignant behaviours in numerous types of cancer (42). Additionally, STAT3 plays a crucial role in the STAT3 signalling pathway, which has been shown to be involved in several cellular functions, including cell proliferation, survival and metastasis (42). Based on these results, ATX may be a target of STAT3. STAT3 may represent a drug target and STAT3 inhibitors may play a role in the treatment of pancreatic neuroendocrine neoplasms.

In conclusion, the present study has demonstrated that ATX expression is upregulated in pNEN tissues and is correlated with the metastatic capacity of pNEN cells,
A

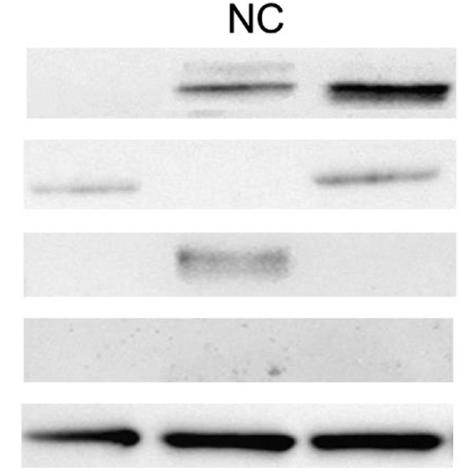

B

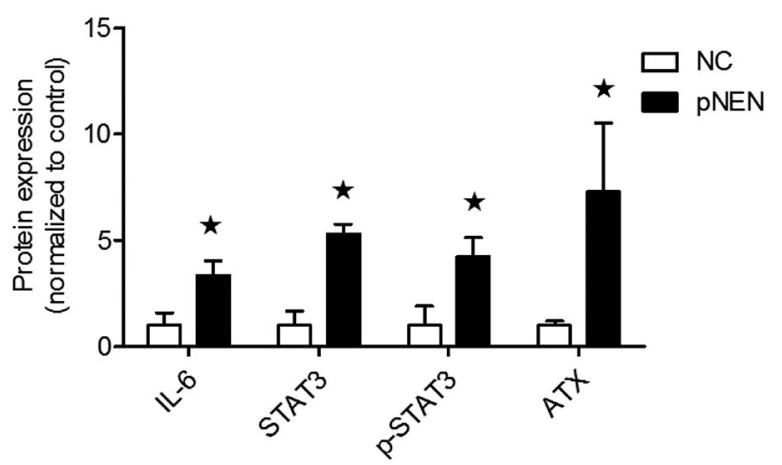

https://ec.bioscientifica.com

https://doi.org/10.1530/EC-18-0356
() 2018 The authors Published by Bioscientifica Ltd
IL-6

STAT3

p-STAT3

ATX

GAPDH

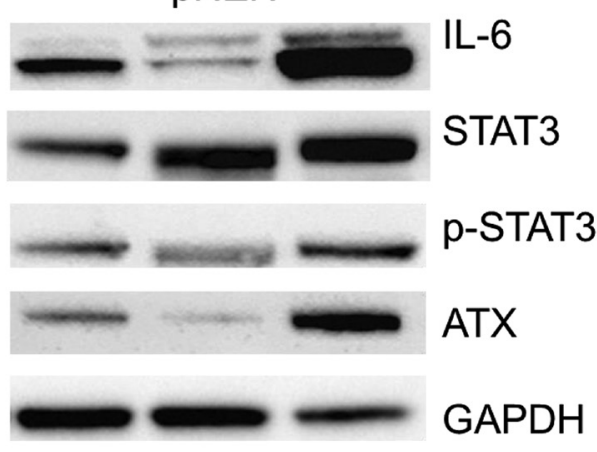

\section{Figure 4}

Impact of IL-6 in pNENs. (A and B) Western blot analysis showing high IL-6 expression in pNEN tissues in comparison to normal control tissues. (A and B) High IL-6 expression levels were associated with significant phosphorylation of STAT3 and increased ATX expression in tumour tissue compared to normal control tissue. All the normal and tumoural tissues were tested and were positive and only representative examples are shown. Data are presented as mean \pm S.D. Student's $t$ test was used for statistics analysis. $\star P<0.01$ vs NC. ATX, autotaxin; NC, normal control; STAT3, signal transducer and activator of transcription 3 . 
A

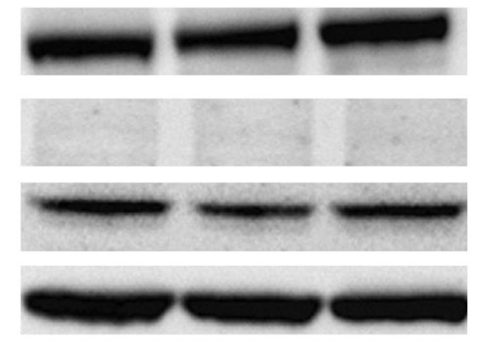

B

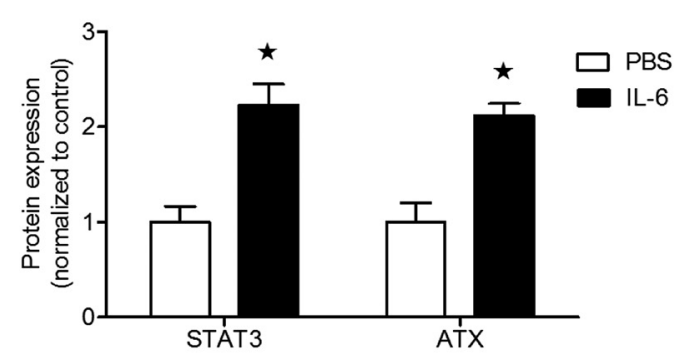

IL-6 treatment

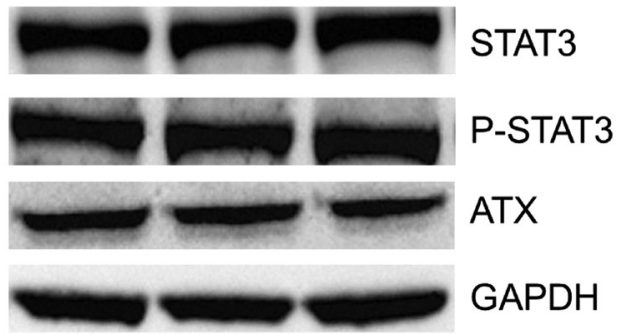

C

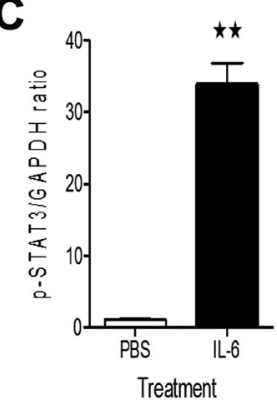

\section{Figure 5}

Impact of IL- 6 on STAT3 activation in BON1 cells. (A) Activation/phosphorylation of STAT3 upon IL- 6 treatment. (B and C) Quantitative analysis showing STAT3, p-STAT3 and ATX are significantly increased upon IL-6 treatment. Experiments were performed thrice and blots are representative of one experiment. Data are presented as mean \pm S.D. of three independent experiments. Student's $t$ test was used for statistics analysis. ${ }^{\star} P<0.05$ vs NC. ${ }^{\star} \star P<0.001$ vs NC. ATX, autotaxin; NC, normal control; STAT3, signal transducer and activator of transcription 3 . potentially via interaction with STAT3 activation. A better understanding of the mechanisms by which ATX regulates pNEN invasive capacity might help to design novel and more effective strategies for the treatment of this disease.

\section{Declaration of interest}

The authors declare that there is no conflict of interest that could be perceived as prejudicing the impartiality of the research reported.

\section{Funding}

Yongchao Yang has been sponsored by the China Scholarship Council (CSC, 201506370096).

\section{Author contribution statement}

Conception and design of experiments: $Y Y$ and $L Y$. Experiments conducted by: $Y \mathrm{Y}$ and $\mathrm{L}$ Y. Data analysis: $\mathrm{X} Y$ and $\mathrm{L} \mathrm{Y}$. Manuscript written by: $L Y$. Revision of manuscript: $L Y, X Y$ and $Y Y$.

\section{References}

1 Dasari A, Shen C, Halperin D, Zhao B, Zhou S, Xu Y, Shih T \& Yao JC. Trends in the incidence, prevalence, and survival outcomes in patients with neuroendocrine tumors in the United States. JAMA Oncology 20173 1335-1342. (https://doi.org/10.1001/ jamaoncol.2017.0589)

2 Ro C, Chai W, Yu VE \& Yu R. Pancreatic neuroendocrine tumors: biology, diagnosis, and treatment. Chinese Journal of Cancer 201332 312-324. (https://doi.org/10.5732/cjc.012.10295)

3 Lawrence B, Gustafsson BI, Chan A, Svejda B, Kidd M \& Modlin IM. The epidemiology of gastroenteropancreatic neuroendocrine tumors. Endocrinology Metabolism Clinics of North America 201140 1-18, vii. (https://doi.org/10.1016/j.ecl.2010.12.005)

4 Ohmoto A, Rokutan H \& Yachida S. Pancreatic neuroendocrine neoplasms: basic biology, current treatment strategies and prospects for the future. International Journal of Molecular Sciences 201718 1-16. (https://doi.org/10.3390/ijms18010143)

5 van Meeteren LA \& Moolenaar WH. Regulation and biological activities of the autotaxin-LPA axis. Progress in Lipid Research 200746 145-160. (https://doi.org/10.1016/j.plipres.2007.02.001)

6 Nam SW, Clair T, Kim YS, McMarlin A, Schiffmann E, Liotta LA \& Stracke ML. Autotaxin (NPP-2), a metastasis-enhancing motogen, is an angiogenic factor. Cancer Research 200161 6938-6944.

7 Federico L, Jeong KJ, Vellano CP \& Mills GB. Autotaxin, a lysophospholipase D with pleomorphic effects in oncogenesis and cancer progression. Journal of Lipid Research 201657 25-35. (https:// doi.org/10.1194/jlr.R060020)

8 Barbayianni E, Kaffe E, Aidinis V \& Kokotos G. Autotaxin, a secreted lysophospholipase $\mathrm{D}$, as a promising therapeutic target in chronic inflammation and cancer. Progress in Lipid Research 2015. 58 76-96. (https://doi.org/10.1016/j.plipres.2015.02.001)

9 Umezu-Goto M, Kishi Y, Taira A, Hama K, Dohmae N, Takio K, Yamori T, Mills GB, Inoue K, Aoki J, et al. Autotaxin has lysophospholipase D activity leading to tumor cell growth and motility by lysophosphatidic acid production. Journal of Cell Biology 2002158 227-233. (https://doi.org/10.1083/jcb.200204026)

10 Lee D, Suh DS, Lee SC, Tigyi GJ \& Kim JH. Role of autotaxin in cancer stem cells. Cancer and Metastasis Reviews 201837 509-518. (https://doi.org/10.1007/s10555-018-9745-x)

11 Moolenaar WH, Houben AJ, Lee SJ \& van Meeteren LA. Autotaxin in embryonic development. Biochimica et Biophysica Acta 20131831 13-19. (https://doi.org/10.1016/j.bbalip.2012.09.013)

12 Jankowski M. Autotaxin: its role in biology of melanoma cells and as a pharmacological target. Enzyme Research 20112011194857. (https://doi.org/10.4061/2011/194857)

13 Levy DE \& Darnell JE Jr. Stats: transcriptional control and biological impact. Nature Reviews Molecular Cell Biology 20023 651-662. (https://doi.org/10.1038/nrm909)

$14 \mathrm{Yu} \mathrm{H}$, Pardoll D \& Jove R. STATs in cancer inflammation and immunity: a leading role for STAT3. Nature Reviews Cancer 20099 798-809. (https://doi.org/10.1038/nrc2734)

15 Proietti CJ, Rosemblit C, Beguelin W, Rivas MA, Diaz Flaque MC, Charreau EH, Schillaci R \& Elizalde PV. Activation of Stat3 by heregulin/ErbB-2 through the co-option of progesterone receptor signaling drives breast cancer growth. Molecular and Cellular Biology 200929 1249-1265. (https://doi.org/10.1128/MCB.00853-08)

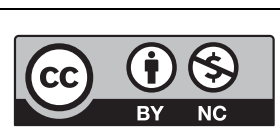

This work is licensed under a Creative Commons Attribution-NonCommercial 4.0 International License. 
16 Chatterjee M, Jain S, Stuhmer T, Andrulis M, Ungethum U, Kuban RJ, Lorentz H, Bommert K, Topp M, Kramer D, et al. STAT3 and MAPK signaling maintain overexpression of heat shock proteins 90alpha and beta in multiple myeloma cells, which critically contribute to tumor-cell survival. Blood 2007109 720-728. (https://doi. org/10.1182/blood-2006-05-024372)

17 Hambek M, Baghi M, Strebhardt K, May A, Adunka O, Gstottner W \& Knecht R. STAT 3 activation in head and neck squamous cell carcinomas is controlled by the EGFR. Anticancer Research 200424 3881-3886.

18 Dhir R, Ni Z, Lou W, DeMiguel F, Grandis JR \& Gao AC. Stat3 activation in prostatic carcinomas. Prostate 200251 241-246. (https://doi.org/10.1002/pros.10079)

19 Aggarwal BB, Kunnumakkara AB, Harikumar KB, Gupta SR, Tharakan ST, Koca C, Dey S \& Sung B. Signal transducer and activator of transcription-3, inflammation, and cancer: how intimate is the relationship? Annals of the New York Academy of Sciences 20091171 59-76. (https://doi.org/10.1111/j.1749-6632.2009.04911.x)

20 Ravishankaran P \& Karunanithi R. Clinical significance of preoperative serum interleukin-6 and C-reactive protein level in breast cancer patients. World Journal of Surgical Oncology 2011918. (https://doi.org/10.1186/1477-7819-9-18)

21 Kim DK, Oh SY, Kwon HC, Lee S, Kwon KA, Kim BG, Kim SG, Kim SH, Jang JS, Kim MC, et al. Clinical significances of preoperative serum interleukin-6 and C-reactive protein level in operable gastric cancer. BMC Cancer 20099 155. (https://doi. org/10.1186/1471-2407-9-155)

22 Groblewska M, Mroczko B, Wereszczynska-Siemiatkowska U, Kedra B, Lukaszewicz M, Baniukiewicz A \& Szmitkowski M. Serum interleukin 6 (IL-6) and C-reactive protein (CRP) levels in colorectal adenoma and cancer patients. Clinical Chemistry and Laboratory Medicine 2008 46 1423-1428. (https://doi.org/10.1515/CCLM.2008.278)

23 Negrier S, Perol D, Menetrier-Caux C, Escudier B, Pallardy M, Ravaud A, Douillard JY, Chevreau C, Lasset C \& Blay JY. Interleukin-6, interleukin-10, and vascular endothelial growth factor in metastatic renal cell carcinoma: prognostic value of interleukin-6 - from the Groupe Francais d'Immunotherapie. Journal of Clinical Oncology 200422 2371-2378. (https://doi.org/10.1200/ JCO.2004.06.121)

24 Azare J, Doane A, Leslie K, Chang Q, Berishaj M, Nnoli J, Mark K, Al-Ahmadie H, Gerald W, Hassimi M, et al. Stat3 mediates expression of autotaxin in breast cancer. PLoS ONE 20116 e27851. (https://doi. org/10.1371/journal.pone.0027851)

$25 \mathrm{Xu}$ A, Ahsanul Kabir Khan M, Chen F, Zhong Z, Chen HC \& Song Y. Overexpression of autotaxin is associated with human renal cell carcinoma and bladder carcinoma and their progression. Medical Oncology 201633 131. (https://doi.org/10.1007/s12032-016-0836-7)

26 Kaffe E, Katsifa A, Xylourgidis N, Ninou I, Zannikou M, Harokopos V, Foka P, Dimitriadis A, Evangelou K, Moulas AN, et al. Hepatocyte autotaxin expression promotes liver fibrosis and cancer. Hepatology 201765 1369-1383. (https://doi.org/10.1002/hep.28973)

$27 \mathrm{Xu}$ Y. Lysophospholipid signaling in the epithelial ovarian cancer tumor microenvironment. Cancers 201810 227. (https://doi. org/10.3390/cancers10070227)

28 Benesch MG, Tang X, Dewald J, Dong WF, Mackey JR, Hemmings DG, McMullen TP \& Brindley DN. Tumor-induced inflammation in mammary adipose tissue stimulates a vicious cycle of autotaxin expression and breast cancer progression. FASEB Journal 201529 3990-4000. (https://doi.org/10.1096/fj.15-274480)

29 Bosman F, Carneiro F, Hruban R, Theise N, et al. Classification of Tumours of the Digestive System. Lyon: World Health Organization. International Agency for Research on Cancer, 2010.
30 Siddique ZL, Drozdov I, Floch J, Gustafsson BI, Stunes K, Pfragner R, Kidd M \& Modlin IM. KRJ-I and BON cell lines: defining an appropriate enterochromaffin cell neuroendocrine tumor model. Neuroendocrinology 200989 458-470. (https://doi.org/10.1159/000209330)

31 Yang Y, Yang L \& Li Y. Neuropilin-1 (NRP-1) upregulated by IL-6/STAT3 signaling contributes to invasion in pancreatic neuroendocrine neoplasms. Human Pathology 201881 192-200. (https://doi.org/10.1016/j.humpath.2018.06.030)

32 Hartmann N, Giese NA, Giese T, Poschke I, Offringa R, Werner J \& Ryschich E. Prevailing role of contact guidance in intrastromal T-cell trapping in human pancreatic cancer. Clinical Cancer Research 2014 20 3422-3433. (https://doi.org/10.1158/1078-0432.CCR-13-2972)

33 Wang R, Yu Z, Chen F, Liao C, Wang Q \& Huang X. Overexpression of ARID4B predicts poor survival in patients with hepatocellular carcinoma. Human Pathology 201873 114-121. (https://doi. org/10.1016/j.humpath.2017.12.012)

34 Livak KJ \& Schmittgen TD. Analysis of relative gene expression data using real-time quantitative PCR and the 2(-Delta Delta C(T)) Method. Methods 200125 402-408. (https://doi.org/10.1006/meth.2001.1262)

35 Majid S, Dar AA, Saini S, Shahryari V, Arora S, Zaman MS, Chang I, Yamamura S, Tanaka Y, Chiyomaru T, et al. miRNA-34b inhibits prostate cancer through demethylation, active chromatin modifications, and AKT pathways. Clinical Cancer Research 201319 73-84. (https://doi.org/10.1158/1078-0432.CCR-12-2952)

36 Fishilevich S, Nudel R, Rappaport N, Hadar R, Plaschkes I, Iny Stein T, Rosen N, Kohn A, Twik M, Safran M, et al. GeneHancer: genome-wide integration of enhancers and target genes in GeneCards. Database 20172017 1-17. (https://doi.org/10.1093/database/bax028)

37 Zhou M, Yang H, Learned RM, Tian H \& Ling L. Non-cellautonomous activation of IL-6/STAT3 signaling mediates FGF19driven hepatocarcinogenesis. Nature Communications 2017815433. (https://doi.org/10.1038/ncomms15433)

38 Kishi Y, Okudaira S, Tanaka M, Hama K, Shida D, Kitayama J, Yamori T, Aoki J, Fujimaki T \& Arai H. Autotaxin is overexpressed in glioblastoma multiforme and contributes to cell motility of glioblastoma by converting lysophosphatidylcholine to lysophosphatidic acid. Journal of Biological Chemistry 2006281 17492-17500. (https://doi.org/10.1074/jbc.M601803200)

39 Yang SY, Lee J, Park CG, Kim S, Hong S, Chung HC, Min SK, Han JW, Lee HW \& Lee HY. Expression of autotaxin (NPP-2) is closely linked to invasiveness of breast cancer cells. Clinical and Experimental Metastasis 200219 603-608. (https://doi. org/10.1023/A:1020950420196)

40 Kehlen A, Englert N, Seifert A, Klonisch T, Dralle H, Langner J \& Hoang-Vu C. Expression, regulation and function of autotaxin in thyroid carcinomas. International Journal of Cancer 2004109 833-838. (https://doi.org/10.1002/ijc.20022)

41 Landskron G, De la Fuente M, Thuwajit P, Thuwajit C \& Hermoso MA. Chronic inflammation and cytokines in the tumor microenvironment. Journal of Immunology Research 20142014 149185. (https://doi.org/10.1155/2014/149185)

42 Yun UJ, Park SE, Jo YS, Kim J \& Shin DY. DNA damage induces the IL-6/STAT3 signaling pathway, which has anti-senescence and growth-promoting functions in human tumors. Cancer Letters 2012 323 155-160. (https://doi.org/10.1016/j.canlet.2012.04.003)

43 Chen MF, Lin PY, Wu CF, Chen WC \& Wu CT. IL-6 expression regulates tumorigenicity and correlates with prognosis in bladder cancer. PLoS ONE 20138 e61901. (https://doi.org/10.1371/journal.pone.0061901)

44 Kumari N, Dwarakanath BS, Das A \& Bhatt AN. Role of interleukin-6 in cancer progression and therapeutic resistance. Tumor Biology 2016 37 11553-11572. (https://doi.org/10.1007/s13277-016-5098-7)

Received in final form 6 October 2018

Accepted 10 October 2018

Accepted Preprint published online 10 October 2018 https://ec.bioscientifica.com https://doi.org/10.1530/EC-18-0356 (c) 2018 The authors Published by Bioscientifica Ltd

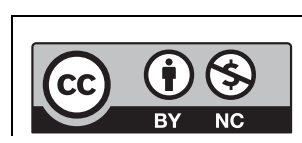

This work is licensed under a Creative Commons Attribution-NonCommercial 4.0 International License. 